\title{
A Materialidade das Palauras: os Mndaimes Linguísticos Expostos na Fala dos Habitantes da Fronteira do Brasil com o Paraguai ${ }^{1}$
}

The Materiality of Words: the SCaffolding Exposed in Language Speaks of the Population the Border with Brazil Paraguay

Regiane Coelho Pereira REIS*

Resumo: Este trabalho revela alguns dos andaimes linguísticos expostos por meio da fala de entrevistados brasileiros moradores em regiões de fronteira situadas entre o Brasil e o Paraguai. Para tanto, analisamos recursos da língua falada como o contexto situacional, o planejamento discursivo, questões acerca do tópico e análise de marcadores conversacionais. Os recortes analisados compõem-se de narrativas orais situadas no final do questionário semântico-lexical que direciona os inquéritos pertencentes ao corpus do Projeto Atlas Linguístico da Fronteira Brasil / Paraguai.

Palavras-chave: Atlas linguístico. Fronteira. Línguas em contato.

Abstract: This work reveals some of the linguistic scaffolding exposed through the speech of brazilians interviewed residents in border regions located between Brazil and Paraguay. For this purpose, we analyze features of spoken language as the situational context, the planning discourse, questions about the topic and analysis of conversational markers. The clippings analyzed consist of oral narratives situated at the end of the questionnaire that directs

* Doutoranda em Estudos da Linguagem pela Universidade Estadual de Londrina. Mestre em Letras pela Universidade Federal de Mato Grosso do Sul (2003). Contato: regiareispereira@yahoo.com.br.

1 Artigo apresentado ao Programa de Pós-Graduação em Estudos da Linguagem da Universidade Estadual de Londrina, como requisito parcial para a conclusão da disciplina Lingua Falada e Interação Verbal, ministrada pelo Prof. Dr. Paulo de Tarso Galembeck, em julho de 2011. 
lexical-semantic investigations pertaining to the corpus of the Linguistic Atlas Project Frontier Brazil / Paraguay.

Key-words: Atlas of languages. Border. Languages in contact.

\section{Introdução}

\section{[... na lingua oral, mais fortemente que na língua escrita, o cognitivo e o situacional permanecem como andaimes visiveis da arquitetura lingüística.} (Ataliba T. de Castilho, 1989, p. 250)

A epígrafe deste trabalho trata de um assunto caro aos estudiosos da linguagem, qual seja: a distinção entre a língua escrita e a falada. A pretensão é discorrer acerca de marcas que subjazem à língua falada, objetivando, pois, expor alguns andaimes que revelam a arquitetura da oralidade de entrevistados fronteiriços. Analiso, sobretudo, as narrativas e os causos contados, num discurso assimétrico (documentador/entrevistado), com recorte para trechos da fala de apenas seis informantes, inseridos num total de 80 entrevistados. Para tanto, este texto encontra-se dividido em: esboço histórico da faixa de fronteira, seguido do aporte teórico utilizado e da análise da oralidade investigada, bem como as considerações finais e as referências bibliográficas.

O corpus analisado centra-se nos inquéritos HF2G2 (ponto 03), MF1G1 (ponto 10), HF1G1 (ponto 08), HF1G2 (ponto 09), HF2G1 (ponto 06) e HF2G2 (ponto 02), que formam o banco de dados do Projeto Atlas Linguístico da Fronteira do Brasil/Paraguai: em busca das interinfluências das línguas em contato. $\mathrm{O}$ referido projeto caracteriza-se como tese de doutorado em andamento, orientada pela Prof. ${ }^{a}$ Dr. ${ }^{a}$ Vanderci de Andrade Aguilera, desenvolvido no Programa de Pós-Graduação em Estudos da Linguagem da Universidade Estadual de Londrina (UEL).

A leitura dos códigos dos entrevistados elenca-se do seguinte modo: H: homem, M: mulher; F1: Faixa etária jovem, F2: Faixa etária idosos; G1 grupo 1: grupo com quatro brasileiros sem ascendência paraguaia; G2 grupo 2: grupo com quatro brasileiros com ascendência paraguaia ou casados com paraguaios, dois homens e duas mulheres por grupo. 
Trata-se de entrevistas aplicadas a oito falantes brasileiros, em cada uma das dez localidades, distribuídas nos dois lados da fronteira, seguindo a linha internacional que divide o Estado de Mato Grosso do Sul, no Brasil, com a República do Paraguai.

\section{Esboço Histórico: a fronteira Brasil/Paraguai}

O Brasil, dadas às suas dimensões geográficas, encontra-se privilegiado em termos de ligações internacionais, pois tem divisas com vários países de fala hispânica. Trato, neste trabalho, especificamente da fronteira entre o Brasil e o Paraguai, na qual se estendem as chamadas cidades gêmeas, ou seja, municípios brasileiros que mantêm contato direto (isto ocorre quando se transita de um lado para outro, mesmo que haja acidentes geográficos entre eles, como rios, por exemplo) com municípios paraguaios ao longo da divisa internacional. Fato incomum delineia a história das duas nações, pois, no passado, a faixa fronteiriça em pauta configurou-se como palco de disputas territoriais, desencadeando, com isso, a chamada Guerra da Tríplice Aliança, episódio sangrento que até os dias atuais ainda traz consigo o sabor amargo do combate que marcou o Brasil e a República do Paraguai (DORATIOTO, 2002).

As marcas da guerra podem ser visualizadas até aos dias de hoje, já que monumentos, placas e nomes de "heróis" que fazem referência a esse episódio histórico são encontrados em terras brasileiras e paraguaias; isto por ser inata, no ser humano, a necessidade do registro de sua história, incluindo-se nesse contexto, os nomes daqueles que contribuíram para ajudar a construir a identidade nacional. Apesar dos conflitos do passado que pairam como pano de fundo histórico sobre os dois povos, trocas linguísticas, culturais e étnicas são perceptíveis na fronteira até mesmo por aqueles que não estão ligados aos estudos da linguagem. A figura 1, a seguir, permite a visualização de esboço da linha internacional que divide o Brasil e o Paraguai, os pontos em vermelho constituem a rede de pontos do projeto do Atlas Linguístico da Fronteira: 


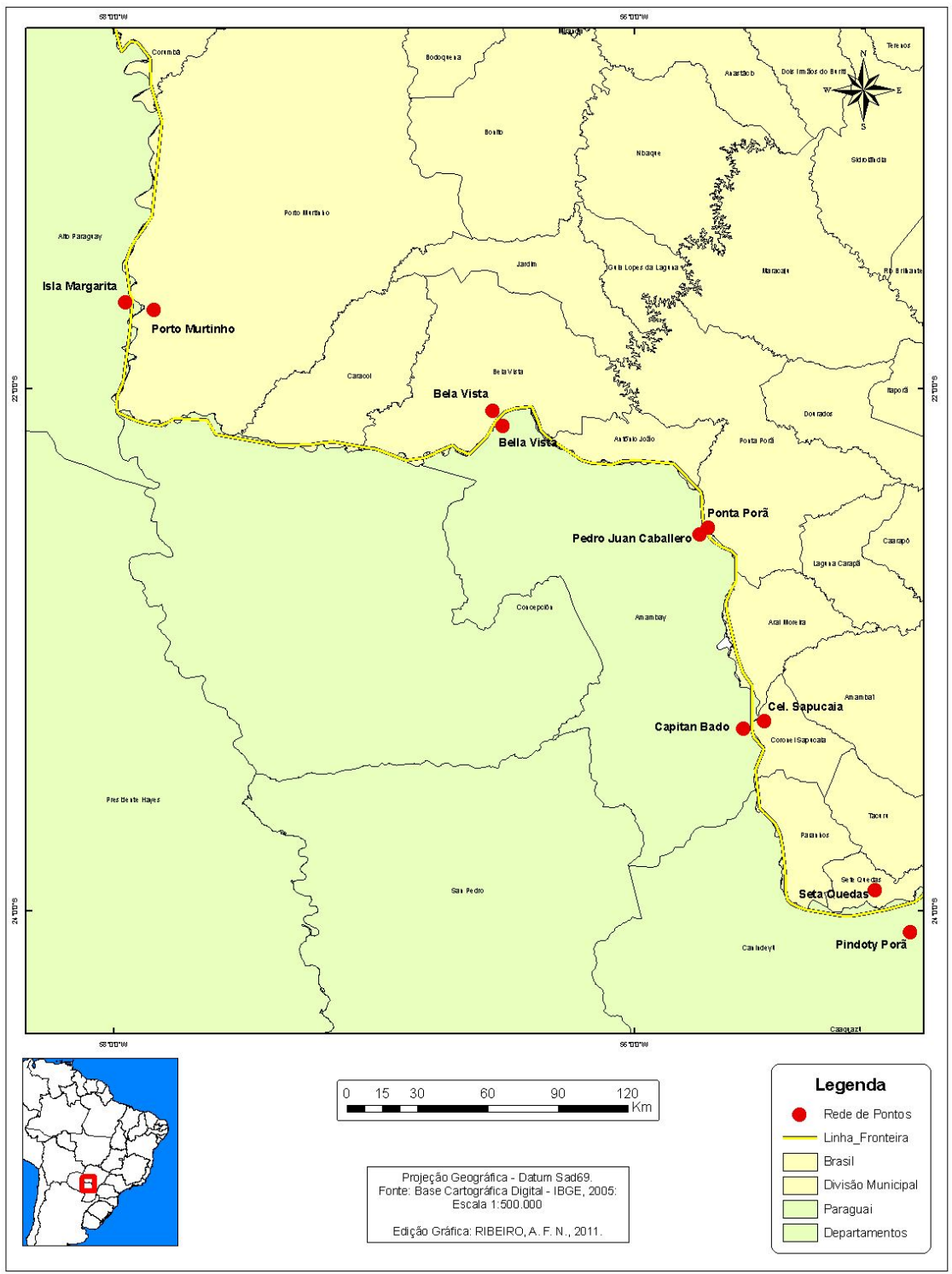

Figura 1 - Esboço da Linha Internacional que divide o Brasil e o Paraguai 


\section{Aporte Teórico}

Diversos são os conceitos ligados à língua. Dentre eles, adoto a concepção de língua como o próprio lugar da interação, concebendo-a do ponto de vista interacional, que resulta de uma série de ações para um determinado fim, isto é, o uso linguístico voltado para o outro. Assim, o locutor cria novos significados ou os redefine, considerando os já existentes, ou ainda, os surgidos a partir da interação com outros sujeitos ou mediante novas realidades que estão postas no ato da comunicação. Por isso, neste artigo, discuto as características gerais da Língua Falada, entendendo-a como a modalidade linguística que possui marcas que a caracterizam de forma peculiar e cujo processo de construção de enunciação traz no seu viés as escolhas do falante. A análise das marcas de Língua Falada revela, portanto, questões como o contexto, a situação de enunciação e as condições de produção do discurso.

Acerca do assunto, Galembeck (1999, p. 111) registra:

[...] os fenômenos que mais de perto caracterizam a língua falada têm uma correspondência direta e imediata com o contexto, e a situação de enunciação e com as condições de produção do enunciado, e não com as categorias do sistema lingüístico (em sentido estrito).

Pelo exposto, é perceptível que intrínsecos aos processos básicos para a análise de amostra de língua falada (LF), numa perspectiva diferenciada em relação à língua escrita (LE), existem questões indispensáveis a fim de gestar uma análise que não mascare os dados colhidos na oralidade, entre as quais encontram-se: i) o planejamento local; ii) o caráter fragmentário da LF, no plano de sequência de assuntos; iii) o contexto comum partilhado pelos locutores; iv) o monitoramento da fala, entre outros. Acresce-se o fato de a maior parte do corpus de LF ser colhido em situação real de uso.

\subsection{Diferenças entre a língua escrita (LE) e a língua falada (LF)}

Desde a mais remota antiguidade, o homem inquieta-se com assuntos que envolvem a linguagem, posto seja exatamente esta particularidade que o difere dos demais animais. Esse fator se instaura, no decorrer da história da humanidade, como peça essencial para a criação de comunidades organizadas 
socialmente. E, por meio da organização social, é que surgem os primeiros indícios de criação da palavra escrita como forma de perpetuar a história dos povos. A título de exemplo, citem-se os desenhos pré-históricos nas cavernas, os hieróglifos dos egípcios, entre tantos outros símbolos criados como registro de uma época. Infere-se que a preocupação com o "escrito" (desenhos e símbolos anteriores aos alfabetos) da realidade de grupos antigos se deu pela necessidade de manter vivas sua cultura, sua história e suas características sociais. A partir daí, segue-se o advento da escrita, propriamente dito, por meio dos alfabetos criados e, desse modo, inaugura-se a história, já que a língua escrita é responsável pela fixação dos avanços de um povo (WEEDWOOD, 2002).

Neste trabalho, não poderia deixar de apontar, ainda que de forma breve, a diferença entre a Fala e a Escrita, inseridas no amplo contexto da enunciação. É sabido que ambas possuem características simultâneas, pois há uma continuidade entre elas. E que também são formas de comunicação que encerram a mesma finalidade: eventos linguísticos que pressupõem interação.

Merece destaque a fala de Chaves (2002, p. 33) sobre a diferença mencionada:

[...] ao relacionar fala e escrita, não se deve compará-las em termos de superioridade ou inferioridade. É mais conveniente relacioná-las dentro de um contínuo sócio-histórico de práticas sociais que envolvem o uso da língua e não na relação dicotômica de pólos opostos.

Em consonância ao pensamento da autora, as duas modalidades linguísticas devem ser consideradas em conformidade com os pressupostos que as regem. Para tanto, faz-se necessário observar as características peculiares que constitui cada uma delas. Baseada em teóricos como Castilho (1989), Fávero, Andrade e Aquino (1999), Galembeck (1989) e Marcuschi (1999, 2001), elaborei o quadro 1, a seguir, que esboça traços particularizadores de LE e LF, sem, contudo, negar a existência desses traços nas duas modalidades analisadas.

Nesse particular, a primeira coluna mostra as características gerais que podem ser atribuídas às LE e LF, mesmo com modos diferenciados de produção do discurso; a segunda coluna diz respeito à Língua Escrita; a terceira, à Língua Falada, a quarta e última coluna, a ambas. 
Quadro 1 - Características gerais da Língua Escrita e da Língua Falada

\begin{tabular}{|c|c|c|c|}
\hline $\begin{array}{c}\text { Características } \\
\text { Gerais }\end{array}$ & Língua Escrita & Língua Falada & LE e LF \\
\hline $\begin{array}{c}\text { Espaço } \\
\text { Temporal }\end{array}$ & $\begin{array}{c}\text { Afastamento no } \\
\text { tempo }\end{array}$ & $\begin{array}{c}\text { Tempo } \\
\text { real/Simultâneo }\end{array}$ & $\begin{array}{c}\text { Ambas } \\
\text { possuem, mas } \\
\text { com } \\
\text { modalidades } \\
\text { distintas }\end{array}$ \\
\hline $\begin{array}{c}\text { Situação } \\
\text { Relativizada }\end{array}$ & $\begin{array}{l}\text { Espaço virtual, } \\
\text { ligado somente } \\
\text { pela leitura } \\
\text { textual }\end{array}$ & $\begin{array}{c}\text { Espaço real, } \\
\text { pois o texto } \\
\text { falado será } \\
\text { ouvido }\end{array}$ & $\begin{array}{l}\text { Espaços } \\
\text { distintos }\end{array}$ \\
\hline Interação & $\begin{array}{l}\text { À distancia (por } \\
\text { meio de leitura) }\end{array}$ & $\begin{array}{c}\text { Simultânea (face } \\
\text { a face) }\end{array}$ & $\begin{array}{l}\text { Varia a } \\
\text { situação }\end{array}$ \\
\hline Realização & $\begin{array}{c}\text { Planejamento } \\
\text { Prévio }^{2}\end{array}$ & $\begin{array}{c}\text { Planejamento } \\
\text { Local }\end{array}$ & $\begin{array}{c}\text { Ambas } \\
\text { possuem }\end{array}$ \\
\hline Organização & $\begin{array}{c}\text { Tende a ser mais } \\
\text { linear/mais } \\
\text { organizada } \\
\text { gramaticalmente } \\
\text { (a padrão) }\end{array}$ & $\begin{array}{l}\text { Organizada em } \\
\text { turnos }\end{array}$ & $\begin{array}{c}\text { Ambas } \\
\text { possuem }\end{array}$ \\
\hline Organização & $\begin{array}{c}\text { Logicidade } \\
\text { gramatical }\end{array}$ & $\begin{array}{c}\text { Emaranhado } \\
\text { gramatical }\end{array}$ & $\begin{array}{c}\text { Ambas } \\
\text { possuem }\end{array}$ \\
\hline Tópico & Maior Centração & Maior Fluidez & $\begin{array}{c}\text { Ambas } \\
\text { possuem }\end{array}$ \\
\hline
\end{tabular}

$\mathrm{Na}$ discussão que se segue, o Quadro 1 deixa à mostra que tanto a LE quanto a LF são consideradas eventos nos caminhos da enunciação, ou seja, são reconhecidas como produtoras de ação, portanto, acontecimento comunicativo. É por esse fato, que o evento, seja ele escrito ou oral, pode

2 Teoria de Shegloff desenvolvida no texto "Elementos Fundamentais da Conversação". 
ser visto como interação, posto não haver evento sem alteração no meio sociocultural. Nesse sentido, analisaremos, ancorada nos pressupostos teóricos dos autores supracitados, modalidades da LF como Contexto Situacional, Processos de Planejamento: tópico discursivo, Marcadores conversacionais e Marcas de oralidade. Esses veios teóricos que permitem analisar trechos de texto oral que serão explicitados no momento da análise. Adentro, a partir de agora, ao próximo tópico deste artigo: as análises dos dados.

\section{Análise de Dados: um passeio pela oralidade de sujeitos fronteiriços}

À análise da língua falada na fronteira precede algumas considerações teóricas. Dentre estas, ancorada nas palavras de Chaves (2002, p. 37), ressalte-se que o estudo da LF exige a consideração de dois princípios básicos: o contexto situacional e o planejamento local do discurso. Segundo a autora, em termos de oralidade, na fala, os interlocutores se encontram face a face, desencadeando a construção do enunciado e a interação verbal ao mesmo tempo. Em contrapartida, na escrita, o leitor não participa da construção do texto. Abordarei, em primeira instância, o contexto situacional.

É sabido que numa situação de fala determinada, o enunciado é desenvolvido entre os locutores, documentador (Doc.)/ entrevistado (Inf.), por exemplo, resultando na atividade humana que envolve "duas ou mais vozes", o que ocasiona o texto conversacional com papéis pré-definidos para cada participante, neste caso, o contexto situacional é o de uma entrevista (RODRIGUES, 2001, p. 18). Observem-se algumas referências ao contexto situacional no trecho do inquérito HF2G1 (ponto 04) transcrito ${ }^{3}$ :

1. Doc. Como é chamado o homem casado que a mulher engana com outro homem?

Inf. Eu não respondi essa para a senhora?

Doc. Não!

Inf. Éh::.... tem muita...

${ }^{3}$ As transcrições das gravações estão sendo realizadas seguindo o modelo metodológico do Projeto Atlas Linguístico do Brasil, ALiB: transcrições grafemática e fonética, esta última apenas do item lexical requerido. Ver: Documentos I do Projeto ALiB. 
Nesse trecho da gravação, o informante demonstra ter ciência de que se trata de entrevista, com questionário que precisa ser respondido. O contexto situacional, o de entrevista, acompanhada de gravador, parece contribuir para deixar o entrevistado um tanto tenso. Todavia, após algum tempo de conversa, essa situação tende a se modificar e, por vezes, até descontrai o interlocutor, que chega a sorrir, como no trecho abaixo, momento em que a informante MF1G1 (ponto 10) discorre acerca das artes de infância:

Inf. E otra do juelho, eu tava correndo pa (= para) pegá minha irmã em volta da fita que corta madera na serraria também, rebentei o juelho, teve que dá uns doze ponto no juelho.

Doc. Meu Deus!

Inf. Uma bomba (risos), uma bomba.

No caso dos diálogos sob análise, é perceptível o valor da conversação como ato de fala especial, único, individual, do ponto de vista de cada locutor, e que

... corresponde a uma interação verbal centrada, que se desenvolve durante o tempo em que dois ou mais interlocutores voltam sua atenção para uma tarefa comum, que é a de trocar idéias sobre determinado assunto. (RODRIGUES, 2001, p. 18).

Nesse particular, o contexto situacional exerce influência sobre o processo de interação verbal entre interlocutores, o que pode ser afetado se o ambiente da gravação não for adequado, provocando desajustes na interação. $O$ contrário também exerce influência sobre o contexto, pois que o ambiente propício para aplicação de inquérito favorece o levantamento de informações sobre ele, mesmo tendo como ferramenta somente o áudio da interação verbal.

Em segunda instância, abordo, neste estudo, os processos de planejamento discursivo em Língua Falada. Para tanto, é preciso discutir como se instaura o tópico em meio à conversação. Vimos que o corpus do estudo é formado por interação verbal em forma de entrevista entre um documentador e um entrevistado, por inquérito, portanto, são dois interlocutores inseridos em cada contexto. Apesar dos assuntos serem pré-estabelecidos pelo documentador, o entrevistado tem liberdade de 
abordar o tema da conversação de forma relativamente livre. Desse modo, infere-se que o diálogo começa pelo tópico que motivou a interação entre os sujeitos. O tópico será entendido como aquilo acerca do que se fala, desenvolvido por interlocutores, cujas propriedades essenciais são: i) a centração, que acontece quando se fala de alguma coisa, usando refenciação explícita ou inferível apreendida pelo contexto; ii) a organicidade, que gira em torno da organização do discurso em subtópicos ou tópicos menores que permitem visualizar a linearidade da fala: a continuidade e a descontinuidade; iii) a segmentação, que pode ser compreendida como pequenas porções tópicas, baseadas no princípio da centração; e iv) a digressão, que é definida como uma parte da conversação que não está diretamente ligada ao tópico em andamento (FÁVERO, 2001, p. 39-50). Vejamos o exemplo do inquérito HF1G2 (ponto 09), a seguir:

01. Doc. O que você acha que dá sorte?

Inf. Dá sorte?

Doc. É.

Inf. Num tem nada não que me dá sorte assim. Algum objeto, alguma coisa assim que você tá querendo dizê?

05.Doc. Não, qualquer coisa que você acha que traz sorte pra você. Alguma crença sua...

Inf. Num... eu num tenho isso comigo, não. Assim, por exemplo: "Ah, você fez aquilo lá? Foi sorte, né?". Às veze quando a pessoa fala isso parece que foi... foi tipo uma ((palavra pejorativa)) sua, né?, se você acerto aquilo lá acho que eu num gosto disso,

10. não. Tá você, por exemplo: "Ah você acertô aquela questão na prova, né? Foi sorte sua, né?”. Aí eu vou falá: “Não, eu estudei” (risos), num foi sorte, né? Às veze a pessoa acha que, né. Fica meio, eu num gosto muito disso não.

Em geral, a conversação, nesse contexto de entrevista, inicia-se com o tópico que motivou a interação e esta acontece até o esgotamento do assunto que está proposto. Neste trecho do inquérito, em particular, nota-se que o tópico é desenvolvido revelando a posição do entrevistado em relação ao tema. E que a interação do documentador encaminha o falante para uma abordagem sobre o tópico "Crença acerca da sorte". Na linha 4, pode-se inferir 
que o entrevistado nega sua atitude pessoal em relação ao tema ("Num tem nada não que me dá sorte assim.”) e, a partir da linha 7, desenvolve-o centrado nessa negativa. Outro fator que chama a atenção, é que o tópico "Crença acerca da sorte" contém apenas um subtópico, que inicia quando o entrevistado cita um exemplo, usando, desse modo, referenciação explícita.

Dentre os conceitos de tópicos, tem-se a organicidade abrangendo outros dois conceitos importantes: o de continuidade e o de descontinuidade. Tomei como exemplo o trecho do inquérito MF1G1 (ponto 10) acerca do tema "História de fantasma", cujo tópico e subtópicos apresentam estes dois traços. Vejamos:

1. Doc. Você nunca ouviu contar nenhuma história de fantasma, por exemplo, algum causo de aparição que alguém contou ou que você viu contar.

Inf. Não, acho que aqui era não.

Doc. Conhece alguma de fora?

5. Inf. Sim, conheço uma do meu pai mesmo.

Doc. Conta pra mim.

Inf. Acho que eles moravam no Paraná, e ele tava no quartel, né? Ele era jovem ainda, acho que ele tinha dezoito ano e já tinha eu e minha outra irmã já. E minha mãe ficava sozinha no sítio, no barraco.

10. Doc. Então você nasceu no Paraguai?

Inf. Não, nasci aqui, mais (= mas) eles... foram pra lá, daí aqui já tinha a outra irmã, né, que... ele teve um problema aí, e foi pará dentro do quartel, né, daí teve que levá a gente pra lá.

Doc. Desculpa a pergunta, mas você morou quanto tempo no Paraguai?

15. Inf. Ah, eu num sei, acho que foi muito poco, poque (= porque) eu era bebê, né. Acho que tinha um ano, né? Então eu num sei, acho que foi o período que ele fico lá. Então ele... Aí nesse barraco, tinha minha mãe escutava de noite, assim batendo, como se fosse loça na bacia, né? Barulho de copo assim, diz que era a noite intera, não dexava eles dormi. E aí, e aí ela falava pra ele daí... ele vinha posá em casa, poque tinha duas 20. filha pequena, né? Saia do quartel e vinha posá em casa. Daí um dia ele resolveu, poque eles não dormiam de noite 
por causa do barulho, aí daí diz que ele resolveu, falô: "Eu vô pega esse diabo hoje". Daí quando ele escutô o bleim bleim (= barulho de louça se mexendo) ele abriu que a janela é de corrê, de pau, né? Ele abriu assim e no que ele abriu, diz que veio um negócio branco assim no rosto dele, como se fosse em cima dele, 25. do jeito que veio assim, ele puxo a janela, a janela atravessô lá do otro lado e ele caiu, minha mãe disse que o cabelo dele, tudo, do corpo inteiro, ficava duro assim igual um ispeto, e diz que ele perdeu a fala, perdeu a fala e ficô uma meia mais ou menos sem reação. Tiveram que mudá de lá, diz que era... Eu acredito hoje, né. Como lido com mundo ispirutual, alguma obra de macumbaria por lá, né? Que os demônios ficam 30.pertumbando, né? Eles acreditam como um fantasma, mais a gente sabe que no mundo ispirutual, né... Aí essa é a história que a gente escutô, né?

Em termos de organicidade, temos um supertópico "História de fantasma", seguida do desenvolvimento contextualizado acerca do tema (linhas 7, 8 e 9), em seguida, temos a descontinuidade do tema, já que a fala da entrevistada é interrompida pelo documentador (linha 10) que, logo depois, volta a desenvolver o tópico iniciado pelo marcador "Então ele..." (linha 17). A partir da linha 28, pode-se afirmar que ocorre um processo de segmentação, a inserção de uma pequena porção tópica, ainda baseada no princípio da centração, quando a informante discorre acerca do subtópico "mundo espiritual" (linhas 28 a 31).

Já no inquérito HF2G2 (ponto 03), a título de exemplificação, podese registrar que, ainda ligados à questão do tópico, na linha 3, o entrevistado faz uma digressão baseada no enunciado ${ }^{4}$ quando desvia o assunto para elucidar um fato sucedido com outro sujeito que não participa da conversação (linhas 3 a 7). No decorrer da fala, já na linha 7, faz outro incurso abordando o assunto com nova digressão, momento em que apresenta uma espécie de relação de conteúdo pragmático com o enunciado principal vigente. Apesar de não usar um marcador explícito para fazê-lo. Observe-se o trecho (HF2G2/ponto 02) a seguir:

${ }^{4}$ Cf. Dascal e Katriel, 1982 (apud FÁVERO, 2001, p. 51). 
1. Doc. Poderia contar algum causo ou história de assombração aqui da região...

Inf. Olha, o pessoal conta sempre sobre que aparece pessoas, coisas fantasmagórico, que sempre o pessoal conta que aparece, né? Cachorro preto. Aqui mesmo tinha um irmão que morava aqui nessa casa aqui do fundo ele falou que um dia ele viu... quando 5. ele entrô na casa dele ali ele viu um cachorro preto pulando a cerca, cachorrão grande pulando a cerca e até os mínino dele tinha medo de ficá ali durmindo, sabe, parece que ele presentia a presença do cachorro preto. [...] ele contou que ele viu ali. A gente sempre escuta falá, né? Agora já vi no meu sonho, no sonho eu já vi muito coisa ruim, sabe, coisa em forma de animais, por exemplo, de forma de chacal, em forma de porco, 10. são coisas tipo maligna que vem. Você sabe que a... segundo a história bíblica o demônio se transforma em tudo que ((é)) criatura, né? Uma mulher bonita que se apresenta, um rapaz bonito.

No fechamento do subtópico discursivo, o entrevistado concebe mais uma digressão baseada na sequência semântica inserida anteriormente (linhas 10 a 12), quando o faz como ato de fala informativo (FÁVERO, 2001, p. 52), como se observa no trecho a seguir: "Você sabe que a... segundo a história bíblica o demônio se transforma". Para tanto, apropria-se do marcador "Você sabe que..." que denota o envolvimento entre os interlocutores, recurso utilizado, anteriormente, também nas linhas 2 e 8 (“Olha, o...”/ “Agora já...”).

Outro exemplo de digressão está centrado na fala do informante HF2G2 (ponto 03):

Inf.- ...Tinha trêis pessoa que você tava olhando, colocava o nome das trêis ou das duas, aí enrolava num papel, aí colocava dentro da água. O que abrisse primero, que o papel é a... Molhando ele ia abri, né? O que caísse primero, o que, o que afundasse primero, você pegava e abria que a pessoa queria fica com você. Virava o santo de ponta à cabeça... Ah! Minha mãe é católica, né? Ela teve um dia que tava calor, calor, e eu cheguei lá no tanque pa (= para) lavá um tênis assim, cheguei lá e uma image lá, né? Dentro do tanque. Daí eu falei assim: “Ué!”. Daí 
eu peguei e tirei coloquei fora, né? Aí ela chegô lá, depois eu voltei denovo e tava lá dentro dinovo, né? Aí ela falô assim: "Por que você tiro daquilo lá? Tá aqui dentro". Aí ela falo assim: “Ué, é pra dexá aí memo pra quê?”. Daí eu fiquei queto, né? Num falei nada, né? (inint) Reclama co (= com) neto que ela falo que coloca ali dentro vai chovê, né? Daí eu falei: “Ah! Então ta bom" (risos).

Acerca do trecho explicitado, intento pontuá-lo, pois referencia a digressão quando introduz novo assunto, seguido da retomada do tópico anterior. Este percurso narrativo extraído da fala do informante pode ser auferido, dependendo do ponto de vista do analista de língua falada. Se situada em outro contexto, a fala poderia ser interpretada como descontinuidade e não digressão.

No contexto presente, a interpretação realizada se pauta na construção linguística que remete a assunto não contextualizado anteriormente no ato dessa fala e posterior retomada do tópico inicial. Daí a conclusão de que se trata de digressão, já que Preti (1991, p. 80) atribui à digressão o romper do tópico em pauta, fator que desencadeia sua retomada mais adiante pelo usuário da língua.

Já o planejamento discursivo configura-se como importante conceito que deixa transparecer, nitidamente, as diferenças entre o modo de produção do discurso escrito e do falado. Conforme o já dito, por ser a língua falada planejada localmente, as marcas de oralidade são ferramentas que permitem a análise formal de sua estrutura. $\mathrm{Na}$ análise desse trecho de língua falada pelo habitante fronteiriço, em particular, o planejamento caracteriza-se como temático posto ser direcionado a priori pelo documentador (RODRIGUES, 2001, p. 20). O inquérito HF1G1 (ponto 08) demonstra esse tipo de ferramenta linguística:

1. Doc. Como chama a chuva forte que dá e passa logo?

Inf. Chuva de verão, chuva passagera, não, ai é chuva de verão memo.

Doc. Essa que você falou passageira é falada aqui?

Inf. É chuva passagera, igual lá no norte memo, tem outra nomeação, né?

Doc. Aqui ele falam assim? 
6. Inf. É chuva rápida. Aqui não chove tanto assim. Quando chove, chove direto mesmo.

O discurso do entrevistado encontra-se organizado em consonância à temática proposta pelo documentador, sob o tema "chuva que passa logo", como revelam as linhas 2, 3 e 6 .

É sabido que existem elementos tipicamente recorrentes na linguagem oral. Dentre estes, situam-se os marcadores conversacionais, que não constituem a significação global no processo de interação, mas contribuem sobremodo para formar o conteúdo discursivo-interativo do texto oral. Desse modo, quanto ao aspecto formal, os marcadores podem ser divididos em linguísticos e não linguísticos: o primeiro refere-se aos lexicalizados (sabe?)/ não lexicalizados (ahn) e prosódicos (pausas e alongamentos); já o segundo, diz respeito a olhares, risos, gestos. E, ainda, em simples (sabe?), compostos (quer dizer, no fundo), oracionais (acho que) e combinados (mas acho que) (URBANO, 1993, p. 85-90).

Nessa concepção fundamentada, intento analisar, rapidamente, a fala oral transcrita no trecho abaixo (HF2G1, ponto 06):

1. Doc. Fale um pouco das artes da infância Sr. M.

Inf. Ah, uma época eu fiz, nós fizemos um carrinho, um carrinho pra carregá... entre eu e meus dois irmãos, aí fizemo, adaptamo, colocamo de madera, madera bruta e fizemos um carrinho pra puxá o outro, de varal, né? Aí eles brincava puxano e um dia eu fui,

5. chamei meu irmão caçula e nós fomo meio na descida e... aí entrei den'do carrinho e ele foi me levá, né? Mas como eu era maior, mais pesado, ele não aguentou e soltou o carrinho, soltou, o carrinho começou a correr em disparada e o carrinho tombou comigo, tinha uns pregão, né? E aí, o prego cortou minha costa, fundo, rasgou minha costa e nós tinha muito medo do meu pai. Meu pai era muito bravo e começo saí muito

10. sangue, nós jogamo terra dentro, terra pra estanca o sangue.

Doc. E então?

Inf. - Aí, sarou.

Doc. Por Deus! E se tivesse uma bactéria, um negócio... 
Inf. É que Deus guarda a gente. Mas muita coisa a gente fazia de entrá dentro de tambor

15. duzentos litro e soltá na baxada e se a pessoa sair rolando, rolando, às vezes, ia longe ou, às vezes, destraviava, né? $\mathrm{O}$ tambor batia, né?, no barranco e cê saía de lá tonto, pra nóis era uma festa, né?

Doc. Naquela época, as crianças eram mais felizes, não é?

Inf. Vixe, e como, viu!

A entrevista transcrita do informante HF2G1 evidencia alguns dos marcadores disponíveis na fala que contribuem para estabelecer a interação entre os locutores. $\mathrm{Na}$ linha 2, observa-se um marcador linguístico não lexicalizado em “ah, uma época”, definido também por Galembeck e Carvalho (1997, p. 832-836) como um marcador de início de turno. Para esses autores, constituem-se marcadores conversacionais de acordo com a seguinte classificação: iniciais (não, mas, acho que, etc.), mediais (né?, sabe?, entende?) e finais (né?, não é?, entendeu?), dependendo da posição que ocupa no discurso, pois o turno não é algo fixo, mas flexível conforme o uso.

Outro marcador conversacional utilizado em larga escala na oralidade é o "né?”, como se observa nas linhas 4, 6, 8, 16 (turnos mediais) e 17 (turno final). A análise dos marcadores conversacionais conduz a conclusão de que, dependendo da posição do marcador, este pode exercer função igual ou semelhante no texto falado.

Do ponto de vista interacional, outro recurso perceptível na análise da fala do informante HF2G1 é a pausa. Observe-se:

1. Doc. Conta alguma história dele (= do Pombeiro, tipo de fantasma no Paraguai), então, Sr. M.

Inf. Ah, dizem, dizem o pessoal aí, né? Que ele, esse pombero diz que gosta sempre que deixem um cigarro pra ele e pinga... e se ocê não deixá diz que traz azar... mexe com

5. galinha, mexe com porco, solta vaca...

Doc. E se fizer isso com ele, o que ele fará?

Inf. Aí diz que fica amigo, diz que não faz nada.

A pausa, nas linhas 4 e 5 , indica o caráter do planejamento local do locutor, já que esse recurso permite construir a interação mediante o face a 
face com o interlocutor; no contexto aqui exposto, quem exerce esse papel é o entrevistado.

Como marcador não linguístico, torno a citar o riso do informante como no caso do inquérito HF1G2 (ponto 09):

10. não. Tá você, por exemplo: "Ah você acertô aquela questão na prova, né? Foi sorte sua, né?”. Aí eu vou falá: “Não, eu estudei” (isos), num foi sorte, né? Às veze a pessoa acha que, né? Fica meio, eu num gosto muito disso não.

Isto se dá porque o não linguístico torna-se de fácil apreensão quando há a gravação da entrevista em vídeo, o que não ocorreu na aplicação dos inquéritos do Projeto Atlas Linguístico da Fronteira Brasil/Paraguai, pois estes foram realizados apenas com gravadores de áudio (Panasonic digital RQT9364-1E).

Os trechos de inquéritos apresentados não foram exaustivamente analisados, se assim o fossem, certamente teríamos uma investigação mais densa do que a apresentada nesse texto.

\section{Considerações Finais}

$\mathrm{Na}$ materialidade das palavras, tentei expor alguns dos andaimes que compõem a arquitetura da língua falada na fronteira do Brasil com a República do Paraguai. As nuances apresentadas permitem afirmar que o texto conversacional, apesar do seu caráter fragmentário, pertence ao coletivo e se produz na interação entre locutores do discurso e, o mais interessante, contrariamente à opinião do senso comum, organizadamente. Isto ocorre mediante a imprevisibilidade em relação à estrutura do texto falado, aspectos expostos na fala dos interlocutores da fronteira em pauta.

Mediante o exposto, ancorada nos autores investigados, posso afirmar que o texto conversacional constrói-se de forma dialógica, já que se materializa no coletivo, fator que atribui à fala caráter subjetivo.

No caso específico desse estudo, cumpre salientar que, no terreno de língua falada, a análise não deve ser solidificada a partir de diagnósticos absolutos, sem a possibilidade de reconstrução das discussões acerca dos elementos do texto oral. Há sempre a possibilidade de novas incursões pela oralidade, dependendo do ponto de vista do observador. 


\section{Referências}

CASTILHO, A. T. de. Português culto falado no Brasil. Campinas:

UNICAMP, 1989.

CASTILHO, A. T. de. A Lingua falada no ensino de português. São Paulo: Contexto, 1998.

CHAVES, A. P. Manifestações da lingua falada em narrativas escolares. 2002. Dissertação (Mestrado em Linguística e Língua Portuguesa) Universidade Estadual Paulista Júlio de Mesquita Filho, Araraquara. 2002.

DORATIOTO, F. Maldita guerra: nova história da Guerra do Paraguai. São Paulo: Companhia das Letras, 2002.

FÁverO, L. L. O tópico discursivo. In: PRETI, D. (Org.) Análise de textos orais. 5. ed. São Paulo: Humanitas, 2001.

GALEMBECK, P. de T. Unidade discursivas na fala culta de São Paulo. (texto inédito - cópia do autor).

GALEMBECK, P. de T. Metodologia de pesquisa em português falado. In: RODRIGUES, A. C. de S.; ALVES, M. I.; GOLDSTEIN, N. S. (Orgs.). I Seminário de Filologia e Lingua Portuguesa. São Paulo: Humanitas, 1999.

GALEMBECK, P. de T. O tópico discursivo: procedimentos de expansão. In: PRETI, D. (Org.) Diálogos na fala e na escrita. São Paulo: Humanitas, 2005.

GALEMBECK, P. de T. Língua falada: processos de construção. Cadernos do CNLF, Rio de Janeiro, v. X, n. 2, 2006.

JUBRAN, C. C. A. S. et al. Organização tópica da conversação. In: ILARI, R. (Org.) Gramática do Português Falado. Níveis da análise linguística. 4. ed. Campinas: UNICAMP, 2002.

MARCUSCHI, L. A. Da fala para a escrita. 2. ed. São Paulo: Cortez, 2001.

PRETI, D. A linguagem dos idosos: um estudo de análise da conversação. São Paulo: Contexto, 1991. 
RODRIGUES, A. C. de S.; ALVES, M. I. Língua Falada e Língua Escrita. In: PRETI, D. (Org.) Análise de textos orais. 5. ed. São Paulo: Humanitas, 2001.

RODRIGUES, A. C. de S.; ALVES, M. I.; GOLDSTEIN, N. S. (Orgs.). I Seminário de Filologia e Lingua Portuguesa. São Paulo: Humanitas, 1999.

URBANO, H. Marcadores conversacionais. In: PRETI, D. (Org.) Análise de textos orais. 5. ed. São Paulo: Humanitas, 2001.

WEEDWOOD, B. História concisa da linguística. Tradução Marcos Bagno. São Paulo: Parábola, 2002. 